\title{
Earmarking for global health: benefits and perils of the World Bank's trust fund model
}

\author{
In the third article in this series, Janelle Winters and Devi Sridhar review different types of trust \\ funds and how they fit within the bank's lending mechanism, and discuss the major benefits and \\ risks of the bank's use of the trust fund model for health
}

Over the past 50 years, the World Bank has increasingly relied on resources contributed voluntarily from donors and held separately from its core budget to support projects and activities, particularly for global health. ${ }^{1}$ These resources are known as trust funds. In the case of the bank, these trust funds are synonymous with earmarked, extra-budgetary, and "multibi" aid (bilateral aid channelled through multilateral institutions). ${ }^{23}$ The absolute number and relative proportion of bank assets held in trust has skyrocketed since the early 1990s. In 2011, the bank was trustee to roughly half of the trust funds for official development assistance (ODA) worldwide, ${ }^{45}$ and in 2012-13 about 200 donors contributed $\$ 3.7 \mathrm{bn}$ to more than 1000 World Bank Group trust funds. ${ }^{6}$

\section{Trust fund governance at the bank}

The World Bank Group channels voluntary grants from donors in three major ways: through IBRD (International Bank for Reconstruction and Development) and IDA

\section{KEY MESSAGES}

- Trust funds (non-core voluntary aid) for health projects made up nearly half of the World Bank's total funding for health and social services in 2012-13

- The Bank has four major types of trust funds: IBRD/IDA bank executed trust funds, IBRD/IDA recipient executed trust funds, financial intermediary funds, and IFC trust funds. These funds have distinct purposes, implementation mechanisms, and accountability frameworks

- Benefits of the trust fund system for health include its potential for enhanced flexibility, capitalising on international momentum, measurable project outcomes, and investment in innovative areas or financing mechanisms

- Risks of the Bank's trust fund system for health include its potential for misaligned aid allocation, reduced Bank accountability, and inadequate transparency
(International Development Association) trust funds, financial intermediary funds, and IFC (International Finance Corporation) trust funds. In this article we focus primarily on the World Bank's IBRD and IDA trust funds and financial intermediary funds (table 1, see the first paper of this series for more on the World Bank Group's structure). ${ }^{7}$ At IBRD/IDA, trust funds are classified as bank or recipient executed, depending on the bank's management role. Bank executed trust funds are implemented directly by the bank. ${ }^{89}$ They typically fund technical support for IBRD/IDA country projects, provide seed funding for pilot projects, or contribute to the bank's knowledge agenda. For recipient executed trust funds, the bank hands over implementation of the project to a third party, such as a country's Ministry of Health or a non-governmental organisation. ${ }^{4589}$ These trust funds generally co-finance IBRD/IDA lending operations, finance stand alone projects, or support debt servicing operations. ${ }^{89}$ Some recipient and bank executed trust funds share governance structures called "facilities," ${ }^{410}$ which are designed to increase coordination. To reduce fragmentation and better recover costs from managing IBRD/IDA trust funds, the bank recently announced a policy to replace recipient executed trust funds with "hybrid funds," which will have bank executed components. ${ }^{11}$

Financial intermediary funds are more flexible and complex financing mechanisms that-with rare exceptionsupport global or regional partnerships. For this type of trust fund, the bank negotiates a customised agreement with implementing agencies, which generally makes the bank trustee of funds from multiple donors. ${ }^{4912}$ In some cases, the bank's role is restricted to holding, receiving, and transferring commitments on behalf of legally independent implementing agencies (for example, the Global Fund to Fight AIDS, Tuberculosis and Malaria), while in others the bank is both trustee of and major donor to the fund (for example, the African Programme for Onchocerciasis Control). Finally, IFC trust funds typically finance advisory services to businesses and governments, as part of its institutional mandate to promote private sector investment in developing countries. An example is the \$1bn Health in Africa Initiative, which is designed to channel funds for private health facilities and healthcare delivery and has received donor support through small trust funds and a large private equity fund..$^{1314}$

Collectively, trust funds allow the bank to increase its income and role in global activities. At the end of 2016, the bank served as steward to about $\$ 11 \mathrm{bn}$ in trust fund resources at IBRD, IDA, and IFC, and held \$23bn in financial intermediary funds. ${ }^{15}$ These resources finance a considerable proportion of the bank's staff and operations, including over $60 \%$ of all global partnerships and nearly two thirds of the bank's advisory and analytics work. ${ }^{15} 16$ In 2013, trust fund revenue was almost as substantial as that of the entire IDA. ${ }^{16}$

\section{Trust funds for health: a 2012-13 snapshot}

How much of this trust fund portfolio is dedicated to health projects? According to statistics reported by the bank in 2013, about half of the cumulative commitments to financial intermediary funds to date was for the health sector (fig 1). In 2012-13 alone, cash contributions to financial intermediary funds for the health sector totalled around $\$ 3.9 \mathrm{bn}$, or $37 \%$ of the total cash contributions to bank trust funds. ${ }^{9}$ The same year, recipient executed trust funds handed out about $\$ 430 \mathrm{~m}$ to the health and social services sector, which represents around $4 \%$ of the total disbursements from bank trust funds (fig 2). ${ }^{917}$ Data are not available on bank executed trust fund financing for the health sector, but their relative contribution to the health sector is small as bank executed trust funds for all sectors accounted for just $6 \%$ of all trust fund disbursements in 2012-13. ${ }^{9}$ To put these numbers in perspective, IBRD/IDA lending for core health and social services projects was just over \$5n in 2012-13. ${ }^{18}$

\section{Benefits of the trust fund model for health}

What has driven the bank to increasingly turn to trust funds to finance health projects? Firstly, the flexibility of trust funds 


\begin{tabular}{|c|c|c|c|c|c|c|}
\hline & General purpose & Bank role & Donors & $\begin{array}{l}\text { Geographical } \\
\text { focus }\end{array}$ & Accountability & Fees \\
\hline $\begin{array}{l}\text { IBRD/ } \\
\text { IDA Bank } \\
\text { Executed Trust } \\
\text { Fund (BETF) }\end{array}$ & $\begin{array}{l}\text { Project analytical and } \\
\text { advisory services; project } \\
\text { administration; bank's } \\
\text { knowledge agenda }\end{array}$ & $\begin{array}{l}\text { Implementation. } \\
\text { Funds support bank's } \\
\text { work programme }\end{array}$ & $\begin{array}{l}\text { Single donor } \\
\text { (majority); } \\
\text { multi-donor }\end{array}$ & $\begin{array}{l}\text { Country projects } \\
\text { (majority) }\end{array}$ & $\begin{array}{l}\text { Subject to bank administrative (not } \\
\text { operational) policies; bank prepares } \\
\text { terms of reference, procures goods/ } \\
\text { services, makes payments, and } \\
\text { submits financial and programme } \\
\text { reports to donors }\end{array}$ & $\begin{array}{l}\text { Indirect rate of } 17 \% \text { of personnel } \\
\text { costs charged on disbursement }\end{array}$ \\
\hline $\begin{array}{l}\text { Financial } \\
\text { intermediary } \\
\text { fund (FIF) }\end{array}$ & $\begin{array}{l}\text { Providing complex } \\
\text { trustee services for funds } \\
\text { transferred to multiple } \\
\text { implementing agencies }\end{array}$ & $\begin{array}{l}\text { Financial trustee. } \\
\text { Customised } \\
\text { administrative, } \\
\text { financial, or } \\
\text { operational services }\end{array}$ & $\begin{array}{l}\text { Multi- } \\
\text { donor (vast } \\
\text { majority) }\end{array}$ & $\begin{array}{l}\text { Regional and global } \\
\text { programmes (vast } \\
\text { majority) }\end{array}$ & $\begin{array}{l}\text { Case by case operational, } \\
\text { administrative, and financial policies. } \\
\text { Standard bank policies do not apply }\end{array}$ & $\begin{array}{l}\text { Case by case. Cost recovery policy } \\
\text { generally applies }\end{array}$ \\
\hline
\end{tabular}

allows the bank to raise funds from a diverse group of donors for priority countries, while retaining the bank's trusted financial management services. ${ }^{61617}$ Core IBRD/IDA programmes can accept contributions only from governments, but trust funds can accept funding from the private sector. This is especially important for vertical (disease specific) funds: corporations like Exxon Mobil and pharmaceutical companies have contributed to health trust funds, and the Bill and Melinda Gates Foundation was the second largest donor to the recent replenishment of Gavi, the Vaccine Alliance. ${ }^{619}$ New financing mechanisms for many vertical funds also entice donors by allowing them to make programme and budgetary decisions. The Global Fund and Gavi, for example, have their own legal charters and a board of directors on which for-profit private sector representatives have voting power. ${ }^{20}$ Finally, trust funds can channel funding to countries that are not members of the bank or do not choose to invest in global public goods. ${ }^{6}$ For instance, the Avian and Human Influenza Facility raised \$126m for avian influenza surveillance and control in 2006-13 and allocated some of this funding to "weak link" countries that were not prioritising influenza control interventions. ${ }^{21}$

Secondly, rapid agreement and disbursement of funds allows trust funds to channel the requests of specific donors in the context of specific international events or initiatives. ${ }^{56}$ Donors have explained that they earmark aid because it allows them to respond more quickly to emerging challenges. ${ }^{6}$ Most trust funds are able to disburse funds more rapidly ${ }^{22}$ than core IBRD/IDA funding mechanisms because they sidestep traditional bank administrative and operational processes. For example, unlike in core lending, the bank's board of executive directors usually are not required to approve trust fund proposals. ${ }^{23}$ Such ability to harness political momentum has been crucial to start up many global health programmes targeting infectious diseases. ${ }^{419} 20$

Thirdly, the narrowly defined goals and measurability of outcomes of trust funded projects make them attractive to donors. ${ }^{6}$ Trust funds for communicable disease control have increasingly dominated the bank's trust fund portfolio over the past 15 years (figs 1 and 2). ${ }^{512}$ Some private donors to these funds-particularly the Gates Foundation-have strong preferences

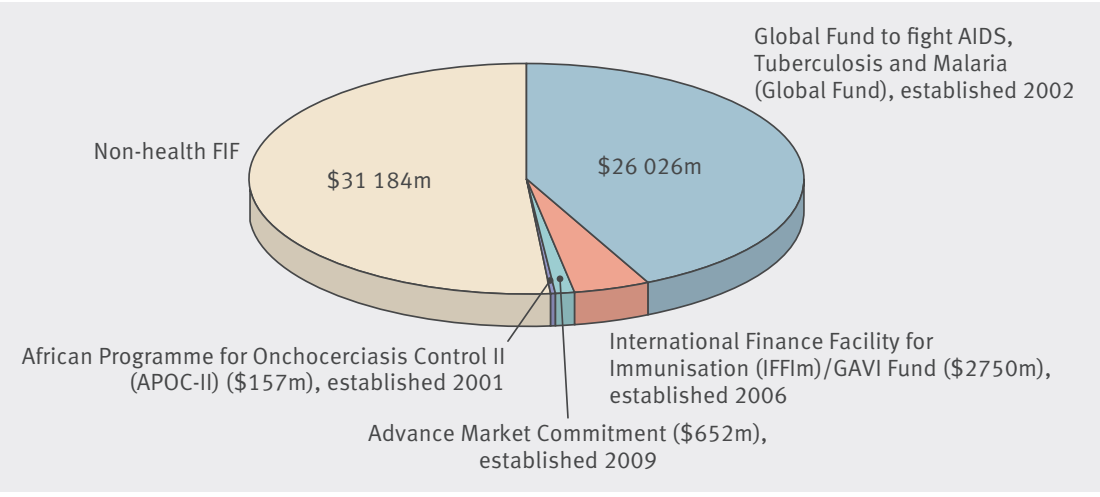

Fig 1 | As of June 2013 , the health sector represented $48.7 \%$ of active financial intermediary fund (FIF) cumulative funding. Based on data from World Bank annual trust fund report (2013) for financing technological and disease specific interventions. ${ }^{2425}$ The outcomes of these grants are usually measured by simple metrics, like the number of bed nets, vaccines, or drug tablets distributed in specific countries. ${ }^{26} 27$ Furthermore, because public and private donors to trust funds are often able to earmark their commitments to specific regions or activities, they are able to trace what their aid is buying at the country level. ${ }^{6}$

Finally, trust funds permit the bank and donors to support innovative regional and global projects that do not fit with the IBRD/ IDA country focused allocation system. The bank has highlighted how trust funds allow it to expand its global partnerships

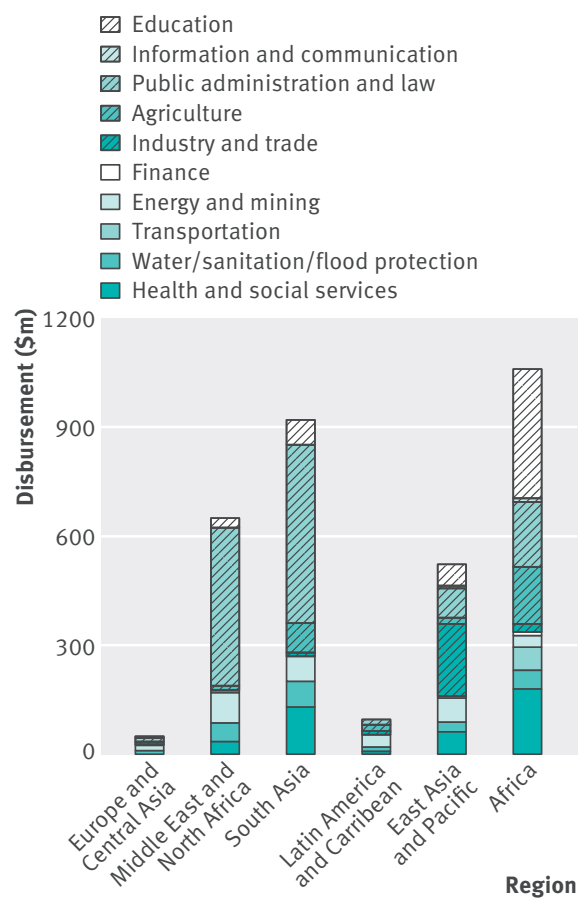

Fig 2 | Africa and South Asia received the largest disbursements of recipient executed trust funds for health in 2012-13. Based on data from World Bank annual trust fund report (2013) 
for global public goods, emergency response, novel focuses (like gender), and, crucially, the control of communicable diseases. ${ }^{4101215}$ Several health trust funds have also allowed the bank to fundraise in new ways or to pilot new financing mechanisms. For instance, the bank has used trust funds to incentivise IDA loans for maternal and child health (see paper 4 of this series on the Global Financing Facility ${ }^{28}$ ), to encourage donors to buy down IDA loans for countries investing in polio control, ${ }^{2930}$ and to provide Wall Street based insurance against future global pandemics (see paper 5 of this series on the Pandemic Emergency Financing Facility ${ }^{31}$ ). Similarly, trust funds supporting health results based financing have enabled the bank to pilot performance based financing at a village level before deciding whether to apply this strategy nationwide. ${ }^{4}$

\section{Risks of the trust fund model for health}

Several costs, however, emerge from pursuing this model of investment. One major concern is that the bank has become vulnerable to "Trojan multilateralism" or the increased influence of small groups of donors on its health programming. ${ }^{2232}$ Indeed, major donors have reported that trust funds are a mechanism for bypassing existing allocation systems and influencing the bank's priorities. ${ }^{6}$ This could tilt health funding toward vertical interventions and away from health priorities in the recipient country. ${ }^{223334}$ For instance, the bank's Independent Evaluation Group found that the polio buy down programme focused exclusively on providing polio vaccines and not wider health or social services infrastructure ${ }^{4}$ and that delivery of vertical funds sometimes overburdened weak national health systems. ${ }^{16}$ Addition- ally, two key measures that allow IDA to provide performance based allocation for its core projects-the country policy and institutional assessment and worldwide governance indicators-do not apply to trust funds, which further raises the risk that trust funds might not fit the needs of low income countries. ${ }^{34}$

A second risk is that trust funds erode capacity of core health, nutrition, and population staff and weaken accountability mechanisms at the bank. While trust funds do not tend to increase the total amount of funding that sovereign donors give to the bank, their separate approval and allocation processes might increase transaction costs for the bank and recipient countries. ${ }^{216}$ This can erode capacity of bank staff to supervise other country based health projects ${ }^{16}$ and explains why the bank recently began to charge higher,

\begin{tabular}{|c|c|}
\hline Problem & Examples \\
\hline $\begin{array}{l}\text { Information on } \\
\text { current bank } \\
\text { trust fund } \\
\text { policies and } \\
\text { governance } \\
\text { structures is out } \\
\text { of date and } \\
\text { intermittently } \\
\text { available }\end{array}$ & $\begin{array}{l}\text { - The bank's operational manual (14.40) does not clearly state which types } \\
\text { of trust funds are covered by its policy } \\
\text { - Trust fund information is scattered across the bank's website, and many } \\
\text { links on the bank's Development Finance (DFi) department's vice } \\
\text { presidential unit website, which is responsible for the trust funds and } \\
\text { partnership department, are broken or have not been updated since } 2013 \\
\text { (as of } 1 \text { June 2017) } \\
\text { - It is unclear precisely which environmental and social safeguards } \\
\text { different trust funds must conform to }\end{array}$ \\
\hline
\end{tabular}

\section{Recommendations}

The DFi website should include (or a portal should be created to include): - Document(s) on the current governance and provision of trust funds at the bank (including which units manage different types of trust funds, and contact information)

- Up to date operational and administrative manuals, and clear indications of which trust funds they apply to

- Dated files that announce new trust fund policies like cost recovery - A current, searchable trust fund directory and complete archive of trust fund reports (see below)

- Links to active trust funded programme web pages, and archived pages for former programmes

- Clear guidance, with supporting documentation, of the up to date safeguards that apply to each type of trust fund (and explicit policies for customised agreements of financial intermediary funds)

- A single searchable directory should be created that includes: - A list of previous and current trust funds, with dates of initiation and closure, programme name, trust fund number, and sector

- More detailed information about currently operating trust funds (like in the outdated 2012 version)

- This task might be best accomplished by creating a searchable portal, similar to the World Bank Projects portal that contains financial and non-financial information about all past and present core bank projects trust fund annual reports should be released yearly, and should consistently have:

- Cash contributions and disbursements for each active trust fund - A breakdown of trust funds by type (recipient executed, IFC, etc) - A breakdown of trust funds by sector (health, infrastructure, etc)

- The World Bank Finances datasets should be made more user friendly by including:

- Full trust fund names, numbers, abbreviated programme descriptions, classifications (recipient executed, IFC, etc), and sector

- All trust funds from the advertised period (about 1990 to present) - A regular schedule for being updated

- A category, like in the OECD datasets, for gender or human rights. This would allow researchers to better track how trust funds are contributing to cross-cutting health issues

- The Financial Intermediary Fund Trustee website should contain links to archived webpages for programmes, like the African Programme for Onchocerciasis Control, which recently ended

Many of these issues fall outside of the purview of bank control and will be assisted if the bank releases improved data through its financial datasets. The bank can help by updating AidFlows more often and comprehensively. For the time being, researchers should use IHME and OECD DAC-CRS to track total bank health expenditures judiciously External assistance for datasets must be view often gives only trust fund numbers, with no names or other used to study bank health funding with caution as they exclude many bank trust funds information. Both views were last updated in 2016

- The Institute for Health Metrics and Evaluation (IHME) dataset on development assistance for health does not include most trust funds for health at the bank. It includes Gavi and the Global Fund financial intermediary funds but not most IBRD/IDA trust funds, other financial intermediary trust funds, or IFC trust funds

- The OECD Development Assistance Committee's Creditor Reporting System (OECD-DAC) relies on donors to report their contributions to trust funds and is missing many contributions to bank trust funds. For an example, see the graph in the appendix 
more consistent fees for trust funds. ${ }^{1735}$ The bank's cost recovery framework (charging higher/consistent fees for trust funds) was initiated to prevent capacity erosion-if it charges consistent overhead costs for each trust fund, it can use this income to hire more staff or pay HNP staff directly for their work on trust funds.

There is an especially high risk that trust funds that finance global health partnership programmes will lack oversight and accountability. The bank does not have a central unit to oversee its participation in global partnerships, ${ }^{16}$ and the financial intermediary funds that typically fund these partnerships are not covered under the bank's standard fiduciary, operational, or administrative policies. ${ }^{36}$ Environmental controls, overhead fees, and the public's access to information on financial intermediary funds (FIFs) are therefore variable and not guaranteed. ${ }^{4103738}$ Bank executed trust funds also came under fire in 2015, when it was made clear that they do not fall under the mandate of the bank's inspection panel-the body that countries can turn to if they feel that safeguards have been compromised by a bank project. ${ }^{3940}$

Finally, the bank's recent claim that it is a "champion for transparency and accountability" ${ }^{15}$ in its use of trust funds contrasts with the reality of trust fund data and operations. The bank emphasises its efforts to "reform the trust funds framework" by "defining mobilisation objectives more strategically, simplifying and harmonizing agreements, improving cost recovery, and incorporating these funds more fully into the budgetary allocation process." ${ }^{41}$ It points to the availability of financial and non-financial information about trust funds through AidFlows, the Financial Intermediary Fund Trustee website, and the World Bank Finances platform. ${ }^{415}$ These resources, however, have major transparency problems for members of the public and researchers (fig 3). Figure 3 suggests specific ways in which these problems could be dealt with.

For a summary and in depth illustration of these drivers and potential perils of the bank's health trust funds, see the case study of onchocerciasis programmesfunded by the oldest and longest running trust funds at the bank-in the appendix.

\section{Conclusion}

The health financing landscape has transformed over the past 30 years as private aid flows increasingly overtake official development assistance. ${ }^{42}{ }^{43}$ With this shift, the supremacy of IBRD's non-concessional financing model has ended, and IDA, IFC, and trust fund commitments now dwarf its own. ${ }^{6}$ At the same time, the bank has transformed from a country based lender to a development organisation with representation on the most global partnership programmes in the world. ${ }^{16}$

Trust funds reflect the World Bank's eagerness to capitalise on these private aid flows for global health activities. This business decision largely explains the proliferation of ad hoc administrative and operational policies for IBRD/IDA trust funds and financial intermediary funds. Competitive interests of private investors to IFC also explain its restrictive access to information policy ${ }^{44}$ and customised policies about safeguards. In our view, however, trust funds have operated largely in the shadows and beyond the purview of members of the public, without having to conform to the measures taken to increase monitoring and accountability in the bank's core work. We call on the bank to commit to its "Forward Look" strategy ${ }^{41}$ for a stronger World Bank Group by improving its trust fund transparency (fig 3 gives explicit recommendations) as a first step.

Contributors and sources: JW collected the data, analysed them, and drafted the initial version of the paper. DS helped to conceptualise and design the study and revised the draft. JW is a PhD student at the University of Edinburgh and her research focuses on onchocerciasis control programmes, defining success in global health, and the World Bank. DS holds a Wellcome Trust Investigator Award on the role of the World Bank in global health and is the coauthor of Governing Global Health: Who Runs the World and Why? (OUP, 2017). Data sources included World Bank reports, financial datasets, staff interviews, archived materials, and websites; external reports on multilateral financing; secondary literature on health policy; and archived materials at the WHO, Food and Agriculture Organization, and UN Development Programme.

Competing interests: We have read and understood BMJ policy on declaration of interests and declare that this work was supported by Wellcome Trust [106635/Z/14/Z]. A senior member of the World Bank is on our project's advisory board,

Provenance and peer review: Commissioned; externally peer reviewed.

This article is one of a series commissioned by The $B M$ J based on an idea by the University of Edinburgh. The $B M /$ retained full editorial control over commissioning, external peer review, editing, and publication. Open access fees are funded by the Wellcome Trust.

Janelle Winters, PhD student

Devi Sridhar, professor

Medical School, Edinburgh University, Edinburgh, UK

Correspondence to: I Winters

janelle.winters@ed.ac.uk

Eichenauer V, Knack S. Poverty and poverty selectivity of World Bank trust funds - Policy Research Working Paper 7731. World Bank Group, 2016. http://documents.worldbank. org/curated/en/495141467122731170/pdf/ WPS7731.pdf

Reinsberg B. The implications of multi-bi financing for multilateral agencies: the example of the World Bank. In: Klingebiel S, Mahn T, Negre M, eds. The fragmentation of aid . Springer, 2016: 185 98doi:10.1057/978-1-137-55357-7 13.

Wagner L. How do earmarked funds change the geographical allocation of multilateral assistance?
Working Paper 150. Foundation Pour Les Etudes et Recherches sur le Developpement International (FERDI); 2016 Mar 24. http://www.ferdi.fr/sites/ www.ferdi.fr/files/evenements/presentations/ seminaire afd_- presentation_._wagner.pdf Independent Evaluation Group. An evaluation of the World Bank's trust fund portfolio: trust fund support fo development. World Bank Group, 2011. https://www. oecd.org/derec/worldbankgroup/48081370.pdf

World Bank Group. 2011 trust fund annual report. World Bank Group, 2011. http:// documents.worldbank.org/curated/

en/155091468314367064/2011-trust-fundannual-report

6 Organisation for Economic Co-operation and Development. Multilateral aid 2015: better partnerships for a post-2015 world. OECD Publishing, 2015, doi:10.1787/9789264235212-en. Sridhar D, Winters J, Strong E. World Bank's financing, priorities, and lending structures for global health. BMJ 2017;358:j3339.

8 Huq W. Analysis of recipient executed trust funds. CFP Working Paper Series 5. World Bank Group, 2010. http://siteresources.worldbank.org/CFPEXT/ Resources/CFP_Working_Paper_05.pdf

9 World Bank Group. 2013 trust fund annual report. World Bank Group, 2013. https:// siteresources.worldbank.org/CFPEXT/ Resources/299947-1274110249410/CFP TFAR AR13 High.pdf

10 World Bank. Trust funds at the World Bank - a guide for donors and partners. World Bank Group, 2009. http://siteresources.worldbank. org/EXTEXTINDTRAINI/Resources/Donor Guide_11-03-09.pdf

11 World Bank Group. The World Bank Group modified cash basis trust funds: report on internal control over financial reporting and combined statements of receipts, disbursements and fund balance. World Bank Group; 2016. http:// siteresources.worldbank.org/EXTABOUTUS/ Resources/29707-1280852909811/ FY16SingleAudit.pdf

12 World Bank. Financial intermediary funds: meeting global development challenges through international partnerships. World Bank, c2012. http://siteresources.worldbank.org/CFPEXT/ Resources/299947-1267555827203/FIFBrochure FINAL_Sep22.pdf

13 International Finance Corporation. IFC support to health public-private partnerships. World Bank, 2010. https://www.ifc.org/wps/wcm/connect/ b10f4080498391e2865cd6336b93d75f/IFC Support2Health WEB.pdf?MOD=AJPERES\&CACHEID =b10f4080498391e2865cd6336b93d75f

14 World Bank Group Finances. Paid in contributions to IBRD/IDA/IFC trust funds based on FY of receipt. World Bank Group. https://finances.worldbank.org/ Trust-Funds-and-FIFs/Paid-In-Contributions-to-IBRDIDA-IFC-Trust-Funds-/nh5z-5qch

15 World Bank Group. Fact sheet on World Bank trust funds. World Bank Group, 2017. http:// siteresources.worldbank.org/CFPEXT/Resources/ TFfactsheetapril2017.pd

16 Independent Evaluation Group. Opportunities and challenges from working in partnership: findings from IEG's work on partnership programs and trust funds. World Bank Group, 2014. https://ieg. worldbankgroup.org/Data/reports/opps_and_ challenges from_partnership.pdf

17 World Bank Concessional Finance and Global Partnerships. Trust fund reforms: progress to date and future directions. World Bank Group, 2013. http://siteresources.worldbank.org/CFPEXT/ Resources/299947-1396037011592/TFReform SecM20130285_Public.pdf

18 World Bank. The World Bank annual report 2013. World Bank, 2013. https:// openknowledge.worldbank.org/bitstream/ handle/10986/16091/9780821399378. pdf?sequence $=1$ \&isAllowed $=\mathrm{y}$

19 Distler L. The third channel - new development aid financing in global health. [dissertation] LudwigMaximillans Universität, 2016, https://edoc.ub.unimuenchen.de/19414/1/Distler_Layla.pdf. 
20 Smyth S, Triponel A. Funding global health. Health Hum Rights 2013;15:E58-70.

21 Independent Evaluation Group. Responding to global public bads: learning from evaluation of the World Bank experience with avian influenza 2006-13. World Bank Group, 2014. http://ieg.worldbankgroup. org/Data/reports/avian_flu1.pdf

22 Sridhar D, Woods N. Trojan multilateralism: global cooperation in health. Glob Policy 2013;4:32535doi:10.1111/1758-5899.12066.

23 World Bank. The World Bank operations manual: Bank procedures - trust funds. World Bank; 2015. http://siteresources.worldbank. org/OPSMANUAL/112526 $1124462138612 / 23702154 /$ BP14.40-July2015.pdf

24 Storeng KT. The GAVI Alliance and the 'Gates approach' to health system strengthening. Glob Public Health 2014;9:865-79. doi:10.1080/17441 692.2014.940362.

25 Bill \& Melinda Gates Foundation. What we do. The Bill \& Melinda Gates Foundation. http://www. gatesfoundation.org/What-We-Do

26 Clinton C, Sridhar D. Governing global health: who runs the world and why? Oxford University Press, 2017.

27 Browne S, Cordon R. Vertical funds: lessons for multilateralism and the UN. New York: Future United Nations Development System, CUNY Graduate Center; 2015. https://www.futureun.org/media/ archive1/briefings/FUNDS_Brief25_Jan2015_WHO_ GAVI_GF.pdf

28 Fernandes G, Sridhar D. World Bank and the global financing facility. BMJ 2017;358:j3395

29 International Development Association. Project appraisal document on a proposed credit in the amount of SDR 50.2 million (US\$74.68 million equivalent) to the Islamic Republic of Pakistan fo a third partnership for polio eradication project.
World Bank, 2009. http://documents.worldbank.org/ curated/en/379611468283490193/pdf/476740P AD0P1141010fficialOUse00nly1.pd

30 World Bank. Oxford University. Disease control priorities in developing countries, second edition. International Bank for Reconstruction and Development, 2006. http://documents.worldbank. org/curated/en/632721468313531105/pdf/4146 OOPAPERODi1010fficialOUse00nly1.pdf

31 Stein F, Sridhar D. Health as a "global public good": creating a market for pandemic risk. BMJ 2017:358:j3397.

32 Reinsberg B, Michaelowa K, Knack S. Which donors, which funds? The choice of multilateral funds by bilateral donors at the World Bank. Policy Research Working Paper No. 7441. World Bank. 2015. https://openknowledge.worldbank.org/ handle/10986/22872

33 Hafner T, Shiffman J. The emergence of global attention to health systems strengthening. Health Policy Plan 2013;28:41-50. doi:10.1093/heapol/ CZs023

34 Atun RA, Bennett S, Duran A. When do vertical (stand-alone) programmes have a place in health systems? World Health Organization. 2008. http:// www.who.int/management/district/services/ WhenDoVerticalProgrammesPlaceHealthSystems. pdf

35 World Bank. Bank Directive - cost recovery framework for trust funds. World Bank. 2015. https://policies.worldbank.org/sites/ppf3/ PPFDocuments/090224b082fe398d.pdf

36 World Bank. World Bank policies and procedures operations manual. World Bank. https://policies. worldbank.org/sites/ppf3/Pages/Manuals/ Operational\%20Manual.aspx

37 World Bank. The World Bank environmental and social framework. World Bank. 2017 http://documents.worldbank.org/curated/
en/383011492423734099/pdf/114278-REVISEDEnvironmental-and-Social-Framework-Web.pdf

38 Reinsberg B. The bureaucratic politics of trust funds: evidence from the World Bank. Political Economy of International Organisations Conference 2016 Jan 7-9: Salt Lake City, Utah.

39 World Bank. Letter from Hartwig Schefer to Daniel Caitlin. Subject: World Bank support to Haiti. World Bank. 2015. http://www.accountabilitycounsel.org/ wp-content/uploads/2014/07/WB-Response-LetterHaiti.pdf

40 Bretton Woods Project. World Bank support for mining expansion criticised. 2015 March 31. http:// www.brettonwoodsproject.org/2015/03/worldbank-support-for-mining-expansion-criticised

41 World Bank Group. Forward look - a vision for the World Bank Group in 2030. World Bank Group. 2016 http://siteresources.worldbank.org/DEVCOMMINT/ Documentation/23732171/DC2016-0008.pdf

42 International Finance Corporation. The business of health in Africa: partnering with the private sector to improve people's lives. World Bank Group. 2008. http://documents.worldbank.org/curated/ en/878891468002994639/The-business-ofhealth-in-Africa-partnering-with-the-private-sectorto-improve-peoples-lives

43 Shiffman J. Knowledge, moral claims and the exercise of power in global health. Int J Health Policy Manag 2014;3:297-9. doi:10.15171/ ijhpm.2014.120.

44 International Finance Corporation. Access to information policy. World Bank Group. 2012. http://www.ifc.org/wps/wcm/connect /98d8ae004997936f9b7bffb2b4b33c15/ IFCPolicyDisclosurelnformation.pdf?MOD=AJPERES

Cite this as: $B M J$ 2017;358:j3394

http://dx.doi.org/10.1136/bmj.j3394

\section{6 \\ OPEN ACCESS}

This is an Open Access article distributed in accordance with the terms of the Creative Commons Attribution (CC BY 4.0) license, which permits others to distribute, remix, adapt and build upon this work, for commercial use, provided the original work is properly cited. See: http:// creativecommons.org/licenses/by/4.0/. 